\title{
MENAKAR KONTRIBUSI UU PEMILU TAHUN 2017 TERHADAP PENINGKATAN KETERWAKILAN PEREMPUAN
}

\author{
Juwita Hayyuning Prastiwi \\ Program Studi Ilmu Politik, Universitas Brawijaya, Malang, Indonesia \\ E-mail: juwita.hayyuning@gmail.com
}

\begin{abstract}
ABSTRAK
Lambannya peningkatan jumlah perempuan di parlemen, secara khusus sangat terkait dengan sistem pemilu yang diberlakukan. Di Indonesia, isu keterwakilan perempuan memperoleh tempat sejak diterapkannya kuota 30 persen pada pemilu 2004, namun hingga berlangsungnya Pemilu 2014 jumlah perempuan di parlemen nasional berkurang 22 kursi dibandingkan pemilu 2009. Berkaitan dengan Pemilu 2019 yang akan datang, penelitian ini bertujuan untuk mengidentifikasi serta menganalisis kontribusi UU No. 7/2017 tentang Pemilu terhadap upaya peningkatan keterwakilan perempuan di parlemen dengan fokus yang tidak hanya membahas sistem pemilu proporsional namun juga meninjau sistem kuota serta empat unsur mutlak yang membentuk sistem pemilu seperti district magnitude, nomination, balloting, dan electoral formulae. Proses identifikasi dan analisis dilakukan dengan feminist perspective melalui metode literature review dengan literatur primernya yaitu UU 7/2017 tentang Pemilu. Sebagai kesimpulannya, hasil studi ini menunjukkan bahwa UU 7/2017, baik sistem proporsional terbuka dan ke-empat unsurnya cenderung tidak signifikan terhadap upaya peningkatan keterwakilan perempuan, aksesibilitas perempuan untuk masuk parlemen tetap lemah sehingga kondisi under-represented dari kelompok perempuan tidak akan banyak berubah.
\end{abstract}

Kata kunci: Keterwakilan perempuan, UU No. 7 tahun 2017, sistem proporsional terbuka, sistem kuota, empat unsur sistem pemilu

\section{QUESTIONING THE CONTRIBUTION OF 2017 ELECTION LAW ON WOMEN'S REPRESENTATIVES IMPROVEMENT}

\begin{abstract}
The slow increase of women number in parliament, in particular, are strongly related to the electoral system. In Indonesia. Issue's of women's representation took place since the 30 percent quota was enacted in 2004 elections, but until the 2014 election instead of increasing, the number of women in national parliament decreased by 22 seats compared to the 2009 election. Related to the upcoming of 2019 elections, this study tries to identify and analyzes the contribution of act number 7/2017 about election to increase women's representation, with focus on proportional system and quota system as well as four absolute elements that forms the electoral system such as district magnitude, nomination, balloting, and electoral formula. Identification and analysis process in this study is done with the feminist perspective and used a literature review method with act number 7/2017 as primary literature. As a result, this study concludes that act number 7/2017, both the open proportional system and the four elements more indicate the inability to increase women's representation, women's accessibility to enter parliament remains weak so the under-represented condition of women's group will not change much.
\end{abstract}

Key word: Women's Representation, act number 7/2017, open proportional system, quota system, four electoral system elements

\section{PENDAHULUAN}

Sebagai produk dari proses politik dan hukum, setiap Undang-Undang (UU) yang diberlakukan selain mengikat, juga memiliki dampak baik yang diinginkan maupun tidak diinginkan, baik yang direncanakan maupun tidak direncanakan. Bukan tidak mungkin aturan dalam UU membawa implikasi negatif bagi masyarakat pada umumnya maupun kelompokkelompok masyarakat pada khususnya, seperti kelompok perempuan.

Demikian pula dalam UU Pemilu No. 7 tahun 2017, pembahasan UU yang dirampungkan pada 21 Juli 2017 ini, memiliki peran krusial terkait tatanan demokrasi yang hendak dicapai. Selain implikasi jangka pendek seperti tingkat partisipasi pemilih 
yang mempengaruhi legitimasi. Secara jangka panjang, pilihan keputusan dalam UU ini dapat mempengaruhi stabilitas pemerintahan karena terkait erat dengan jumlah partai yang akan lolos parlemen, stabilitas internal parlemen, hubungan eksekutif-legislatif yang berdampak pada efektivitas presidensialisme, dan yang tak kalah penting secara substantif aturan pemilu akan mempengaruhi derajat demokrasi yang hendak dicapai.

Derajat demokrasi atau derajat pluralisme dapat berarti, apakah sistem pemilu yang disusun hendak mengakomodir kepentingan dari kelompok rentan atau hanya mengakomodir kepentingan dari kelompok dominan di masyarakat. Salah satu kelompok rentan yang sepatutnya terwakili baik secara deskriptif maupun substantifadalah kelompok perempuan. Merujuk pada pernyataan UN Women and UNDP (2015) "as voters, candidates, electoral administrators, or party supporters - they can express their own needs and interests. Decisions better reflect the electorate. Political processes are more inclusive. Democracy is strengthened".

Mendukung pendapat dari UN Women dan UNDP, National Democratic Institute (NDI) pada artikel berjudul "Why Women in Politics" menyebutkan urgensi kehadiran perempuan dalam politik, mereka merumuskan lima latar belakangempirismengapakehadiran perempuan di politik mampu membawa perubahan dalam pengambilan keputusan, antara lain adalah: 1) Women work across party lines, 2) Women lawmakers are highly responsive to constituent concern, 3) Women help secure lasting peace, 4) Women's participation encourages citizen confidence in democracy, 5) Women priorities education, health, and other key development indicators.

Selain karena kebutuhan khusus, situasi khas, dan jangkauan pengalaman perempuan yang hanya mungkin diwakili perempuan, banyak studi menyebutkan bahwa tinggi rendahnya keterwakilan perempuan juga dapat berimplikasi terhadap masyarakat secara keseluruhan. Namun, sampai dengan pemilu terakhir tahun 2014, perempuan masih belum mencapai angka critical mass sebesar 30 persen Tak hanya itu, hasil pemilu 2014 tersebut (di luar Pergantian Antar Waktu) jumlah kursi perempuan mengalami penurunan dari sebelumnya sebanyak 101 kursi pada periode 2009-2014, turun menjadi
79 kursi untuk periode 2014-2019. Belum lagi di tingkatan lokal, dari total 403 DPRD Kabupaten/Kota yang ada di Indonesia, hanya 20 DPRD yang mampu mencapai angka critical mass.

Salah satu dampak dari rendahnya kehadiran perempuan, tercermin dari produk legislasi yang dihasilkan oleh parlemen. Data yang dihimpun Komnas Perempuan menunjukkan, bahwa sampai Agustus 2014 telah ada sebanyak 365 Peraturan Daerah (Perda) yang diskriminatif terhadap perempuan. Sedangkan di tingkat nasional, dapat ditemui RUU yang memuat semangat perlindungan perempuan, namun tidak menjadi prioritas untuk dituntaskan. Misalnya saja RUU PRT/ ART, yang pembahasannya menginjak tahun ke-14 sejak diajukan pada tahun 2004, bahkan di awal tahun 2018 muncul rencana revisi UU Kitab Undang-undang Hukum Pidana (KUHP) yang mengancam perempuan korban kekerasan seksual dengan pidana maksimal dua tahun penjara (Suara PKBI, 2018).

Pada persoalan sistem pemilu, secara historis kuota minimal 30 persen perempuan telah diberlakukan sejak pemilu 2004, dan berikutnya lahir aturan-aturan lain yang mencoba menyokong kebijakan kuota minimal ini. Di antara kebijakan tersebut antara lain adalah zipper system yang termaktub dalam pasal 55 UU 10/2008. Namun kedua sistem ini mengalami titik balik pasca putusan MK yang membatalkan pasal 214 huruf a-e UU 10/2008, sehingga mengubah formula penetapan calon terpilih dari penggunaan nomor urut menjadi suara terbanyak.

Adanya perubahan sistem penghitungan suara menjadi suara terbanyak pada 2008, telah mempersulit akses perempuan ke dalam politik pada pemilu-pemilu berikutnya. Meski pada masa-masa setelahnya muncul aturanaturan baru yang mendukung sistem kuota, komposisi perempuan di parlemen tetap tidak mampu memenuhi kuota.

Seperti pada pemilu 2014, upaya perbaikan angka keterwakilan perempuan selain diakomodir UU 2/2011 dengan ketentuan kuota minimal 30 persen perempuan pada pendirian, pembentukan, serta kepengurusan parpol. UU 8/2012 juga memuat kewajiban parpol menyertakan minimal 30 persen bakal calon perempuan baik untuk pencalonan DPR maupun DPRD. Demi semakin menjamin 
efektivitas keterwakilan perempuan, kedua aturan ini diperkuat oleh PKPU 7/2013 yang memberlakukan sanksi bagi parpol yang tidak memenuhi aturan kuota tersebut.

Dari sisi aturan pemilu, perlindungan terhadap keterwakilan perempuan dari pemilu ke pemilu nampak makin menguat, jumlah perempuan dalam daftar calon juga semakin bertambah. Namun pasca pemilu, hasil penghitungan tetap tidak menggembirakan, karena reproduksi aturan yang ada tidak benarbenar mendasar.

Kontribusi perempuan memang seringkali dianggap tidak penting, dan hal ini meresap dalam kehidupan politik dan terwujud dalam bentuk seksisme kelembagaan (Lovenduski, 2008: 101-102). Dalam seksisme kelembagaan, kebijakan publik yang diproduksi lebih mencerminkan kebutuhan salah satu seks, penyimpangan-penyimpangan yang bias gender terwujud sejak tahap penetapan agenda, formulasi hingga tahap implementasi kebijakan.

Adapun penyebab perempuan di politik (terutama parlemen) berada dalam kategori under-representation tidaklah tunggal, seperti yang disampaikan oleh Pippa Norris dan Ronald Inglehart pada artikel berjudul "Women and Democracy: Cultural Obstacle to Equal Representation", sebagai berikut :

"Structural factors, including levels of socio economic development and the proportion of women in professional and managerial occupations; the impact of political institutions, such as electoral systems based on proportional- representation; and cultural factors, like the predominance of traditional attitudes toward gender roles." (2001: 127-128).

Norris dan Inglehart menyebut adanya tiga penghambat bagi perempuan untuk memasuki dunia politik, namun dari tiga penghambat tersebut, penelitian ini hendak menekankan pada faktor the impact of political institutions, khususnya mengenai electoral system. Mengapa penelitian ini memilih fokus pada sistem pemilu, karena sistem pemilu merupakan faktor yang paling mungkin untuk diintervensi, baik oleh state actors (seperti partai politik dan parlemen) maupun kelompok civil society (terutama akademisi dan NGO) .

Pada momentum pemilu 2019 yang akan datang, akankah UU 7/2017 memberi perubahan positif pada kondisi keterwakilan perempuan ataukah justru sebaliknya? Pada saat pembahasan revisi UU Pemilu, situs DPR RI (Dpr.go.id) menyebutkan beberapa Daftar Inventarisasi Masalah (DIM) yang dianggap krusial antara lain adalah presidential threshold, parliamentary threshold, sistem pemilu proporsional terbuka atau tertutup, sosial media, e-voting, dan sebagainya. Catatannya, tak satupun DIM yang disebutkan menyinggung persoalan keterwakilan perempuan. Demikian pula dengan opsi-opsi yang muncul di akhir pembahasan RUU, tidak satupun dari poin-poin perdebatan tiap opsi menghadirkan perempuan.

Dari sinilah artikel ini berangkat, pertama-tama dengan berupaya mengevaluasi kebijakan afirmasi berupa sistem kuota yang diatur sejak Pemilu 2004 hingga Pemilu 2019 mendatang. Berikutnya, tulisan ini berupaya mengidentifikasi kontribusi dari UU Pemilu 7/2017 terhadap peningkatan keterwakilan perempuan.Meskipundalamprosespembahasan revisi UUnya tidak memperhatikan perempuan, namun bukan berarti urgensi menakar kontribusi UU ini terhadap keterwakilan perempuan juga hilang, karena seperti yang telah disebutkan di awal, tiap kebijakan yang dibuat dapat saja memberikan dampak langsung maupun tidak langsung, sengaja maupun tidak disengaja.

Adapun unsur sistem pemilu pada UU 7/2017 yang secara tidak langsung dapat atau tidak dapat mempengaruhi angka keterwakilan perempuan antara lain seperti, besaran district magnitude yang tidak bergeser dari 3-10 kursi, nomination yang masih berbasis partai politik, balloting yang berhadapan dengan metode penghitungan suara terbanyak, serta electoral formulae yang berubah dari metode kuota dengan varian hare menjadi metode divisor dengan varian sainte lague. Kontribusi terpenting dari artikel ini adalah upayanya untuk menganalisis kontribusi UU 7/2017, serta menyajikan proyeksi terhadap efektivitas tatanan sistem pemilu terhadap keterwakilan perempuan, yang coba dibangun dari UU tersebut.

\section{METODE}

Fokus artikel ini adalah menganalisis kontribusi UU 7/2017 tentang Pemilu terhadap keterwakilan perempuan, untuk mencapainya maka poin-poin yang dianalisis tidak hanya 
pada sistem proporsional terbuka namun juga meliputi empat unsur mutlak yang membentuk sistem pemilu tersebut antara lain district magnitude, nomination, balloting, dan electoral formulae. Guna melengkapi analisis feminis, pembahasan pada artikel ini juga meliputi evaluasi serta proyeksi sistem pemilu tersebut terhadap kebijakan afirmasi berupa kuota perempuan yang telah diberlakukan sejak tahun 2004.

Metode yang digunakan untuk mengupas fokus tersebut adalah metode literature review, maka sumber-sumber kepustakaan dalam artikel ini tidak hanya dipakai untuk menyusun kerangka penelitian atau mempertajam pisau analisis, namun juga dipakai untuk memperoleh data. Menurut Earl Babbie dalam "The Basic of Social Research Fifth Edition":

"the literature review is not about providing "window dressing" in the form of a few citations. Rather, it's about digging into the body of knowledge that previous researchers have generated - and taking advantage of that knowledge as you design your own inquiry." (2011:477)

Berdasarkan pendapat Earl Babbie, Literature review memang bukanlah kumpulan kutipan tanpa makna, namun literature review berarti meninjau hasil-hasil tulisan yang terkait, mencari gap antara tulisan-tulisan tersebut dengan fenomena-fenomena yang terjadi pada konteks penelitian, dari proses itulah penyelidikan dimulai.

Terkait dengan kualitas sumber kepustakaan, artikel ini memilih literatur yang terbagi dalam dua kelompok sumber diantaranya adalah primary source yang meliputi dokumen UU 7/2017 tentang Pemilu serta secondary source yang meliputi seluruh kepustakaan di luar UU 7/2017 antara lain berupa artikel yang menjelaskan, menganalisis, mengkritisi relasi praktek sistem pemilu dengan keterwakilan perempuan di berbagai negara, termasuk di Indonesia. Selain artikel, secondary source juga meliputi berbagai aturan lain tentang pemilu di Indonesia seperti Undang-undang terdahulu dan PKPU.

Melalui proses pengumpulan data yang dilakukan sejak Juni 2017, analisis terhadap sumber-sumber kepustakaan pada artikel ini menggunakan "feminist perspective", yaitu analisis yang berusaha mengungkap pengalaman perempuan dan hubungan gender dari sisi perempuan. Trisakti Handayani dalam buku "Konsep dan Teknik Penelitian Gender" menyebutkan bahwa penelitian yang berperspektif perempuan secara eksplisit memang menyatakan keberpihakannya, yakni berfokus pada masalah perempuan dan mencari strategi untuk merubah keadaan yang tidak menguntungkan perempuan. Apabila dibandingkan dengan riset androsentris yang ilmiah-obyektif sehingga dapat menjebak riset menjadi riset "tentang perempuan", aspek riset dengan "feminist perspective" adalah riset "untuk perempuan" di mana aspek perasaan dan pengalaman perempuan dilibatkan (2008: 66-78).

Pada proses analisis, penyusunan artikel ini dimulai dengan mengidentifikasi, membaca, dan mengevaluasi sumber kepustakaan terkait, lalu mensistesis sesuai dengan fokus artikel ini. Hasil sintesis disajikan dalam sistematika pembahasan antara lain meninjau sistem kuota pada praktek pemilu di Indonesia lalu membahas sistem pemilu proporsional beserta empat unsur yang membentuknya.

\section{HASIL DAN PEMBAHASAN}

Sebelum sampai pada sistem pemilu apakah yang akan efektif meningkatkan kuantitas perempuan di parlemen, pertamatama yang tidak dapat terlewatkan adalah pembahasan bahwa secara mendasar perjuangan keterwakilan perempuan kerap berhadapan dengan prinsip demokrasi liberal. Prinsipprinsip seperti individualisme dan equal opportunity memang tidak serta merta dapat dipenuhi oleh perempuan, mengingat prinsip liberal tersebut membutuhkan karakter yang melekat pada maskulinitas seperti otonomi diri, rasionalitas, kemampuan memilih, dan termasuk kemampuan membuat kontrak perjanjian dengan pihak lain.

Prinsip-prinsip liberal telah menjadi patokan perilaku dalam demokrasi dan menghegemoni, hal tersebut ditandai dengan tiadanya kesadaran aktor politik bahwa terdapat male biased (patriarkis) dalam norma, pelembagaan, serta praktek demokrasi liberal. Nur Azizah (2012) menyebutkan bahwa kendala ini bersifat hegemonik, sehingga upaya untuk menyusun peraturan perundangan tentang pemilu dan partai politik, termasuk pengaturan rekrutmen 
caleg yang tidak menggunakan prinsip liberal akan sangat sulit tercapai. Sebagai dampaknya, aturan-aturan pemilu di Indonesia yang dibangun di atas prinsip ini justru memfasilitasi dominasi laki-laki.

Bukti atas hegemoni prinsip liberal ini di Indonesia, dapat dilihat sejak DPR pertama periode 1950-1955 dan bahkan hingga pemilu terakhir tahun 2014 ketika sistem kuota telah diberlakukan, perempuan di parlemen nasional masih berada dalam kategori underrepresentation. Berikut ini adalah tabel yang menunjukkan jumlah keterwakilan perempuan dari masa ke masa.

Tabel 1. Keterwakilan Perempuan di DPR RI mulai 1950-2014

\begin{tabular}{ccccc}
\hline \multirow{2}{*}{ Periode } & \multicolumn{2}{c}{ Perempuan } & \multicolumn{2}{c}{ Laki-laki } \\
\cline { 2 - 5 } \% & \multicolumn{2}{c}{ \% } \\
\hline $1950-1955$ & 9 & 3,8 & 236 & 96,2 \\
$1955-1960$ & 17 & 6,3 & 255 & 93,7 \\
Konstituante: & 25 & 5,1 & 488 & 94,9 \\
$1956-1959$ & & & & \\
$1971-1977$ & 36 & 7,83 & 424 & 92,2 \\
$1977-1982$ & 29 & 6,3 & 431 & 93,7 \\
$1982-1987$ & 39 & 8,5 & 421 & 91,5 \\
$1987-1992$ & 65 & 13,9 & 435 & 87,0 \\
$1992-1997$ & 62 & 12,5 & 438 & 87,5 \\
$1997-1999$ & 54 & 10,8 & 446 & 89,2 \\
$1999-2004$ & 45 & 9,0 & 455 & 91,0 \\
$2004-2009$ & 61 & 11,09 & 489 & 89,3 \\
$2009-2014$ & 101 & 17,86 & 459 & 82,14 \\
\hline
\end{tabular}

Sumber: Keterwakilan Perempuan di DPR pasca Putusan MK No. 22-24/PUU/-VI/2008, oleh Pusat Penelitian dan Pengkajian Perkara, Pengelolaan Teknologi Informasi dan Komunikasi Kepaniteraan dan Sekretariat Jenderal, Mahkamah Konstitusi RI, tahun 2013

Dalam "feminist perspective", tiap kebijakan yang tidak mempertimbangkan kebutuhan dan kepentingan perempuan dikenal sebagai kebijakan netral gender. Sistem pemilu yang menggunakan logika liberal seperti penjelasan di atas tentu dapat dikategorikan sebagai kebijakan yang netral gender mengingat implikasinya pada hasil pemilu yang didominasi salah satu jenis kelamin. Bahkan pada pemilu pasca reformasi di mana sistem kuota telah diberlakukan, angka keterwakilan perempuan juga tidak terpenuhi signifikan. Sebabnya, sistem suara terbanyak yang dipakai untuk mendapatkan kursi berdampak pada ketatnya kompetisi antar caleg, sehingga proses kampanye pemilu menghabiskan banyak sumber daya. Bagi perempuan, sumber daya yang harus dikeluarkan pada saat kampanye tidak serta merta tersedia, pun jika tersedia tidak mudah untuk digunakan, karena umumnya perempuan masih bergantung kepada bapak atau suami yang memiliki kuasa terbesar pada soal keuangan keluarga.

Tak heran apabila partai-partai politik mengalami kesulitan memenuhi kuota perempuan dalam daftar calon. Dari 2.465 caleg perempuan pada pemilu 2014, sebanyak 69,7 persen adalah non-kader partai, artinya mereka adalah perempuan-perempuan yang selama ini tidak aktif di dalam parpol bersangkutan (Soeseno, 2014:103). Sedangkan pada hasil pemilu, perempuan yang berhasil masuk parlemen umumnya adalah perempuan yang berasal tidak jauh dari lingkaran dinasti politik. Fenomena seperti ini sangat mungkin terjadi ketika kemenangan pemilu yang sangat bergantung pada kemampuan finansial kandidat. Ben Hilman, menyebutkan bahwa sistem daftar terbuka yang berlaku di Indonesia sejak pemilu 2009, berdampak signifikan pada pengeluaran dana kampanye kandidat : "several cadidates who have contested both 2009 and 2014 election report that their campaign costs more than doubled. $K P U$ documents indicate that candidates spent between one and eight bilion rupiah on individual campaigns over and above what political parties spent on campaigns, although official reports tiled by candidates are likely to under report actual expenditure" (2017 : 42-43).

Sebagai akibat dari sistem daftar terbuka yang membutuhkan sumber daya keuangan yang besar ini maka "several women activists and capable parliamentarians have lost their seats and been replaced by women from political dynasties" (Hilman, 2017: 43). Apabila merujuk pada data Puskapol UI terkait basis keterpilihan caleg perempuan DPR-RI periode 2014-2019, sebanyak 36 dari 97 orang, atau sebesar 47 persen berasal dari jaringan kekerabatan dengan elite politik (oligarki). Menurut Jefry Winters "Oligarki adalah dunia yang paling patriarkis di dunia ini. Jika ada kelompok tertentu yang berkuasa karena modalyang banyak, kekuasaan berdasarkan kekayaan, maka biasanya dia akan 
sangat maskulin" (2014: 162). Artinya, sistem pemilu tidak hanya mampu mempengaruhi kuantitas namun juga mampu mempengaruhi kualitas perempuan di mana critical actors sulit muncul. Tak heran, meski jumlah perempuan di parlemen meningkat dibandingkan periode sebelum reformasi, namun kemajuan produk legislasi yang pro gender tidak signifikan.

\section{Tinjauan terhadap Kuota Perempuan}

Indonesia telah menerapkan kebijakan kuota minimal 30 persen perempuan sejak Pemilu 2004 dan menerapkan zipper system sejak Pemilu 2009. Dua kebijakan afirmasi ini diharapkan akan mampu meningkatkan angka keterwakilan perempuan di parlemen karena kemampuannya dalam mereduksi implikasi demokrasi liberal.

Terkait dengan sistemkuota, secara empiris terdapat dua sistem kuota yang umumnya dipakai untuk meningkatkan keterwakilan perempuan, diantaranya yaitu sistem kuota legal atau yang kerap disebut juga sebagai electoral quota atau legislated quota dan sistem kuota partai atau yang kerap disebut sebagai voluntary party quota. Drude Dahlerup pada artikelnya berjudul "Electoral Gender Quota: Between Equality of Opportunity and Equality of Result" menyebutkan sebagai berikut :

"Concerning the mandate, a distinction is made between (1) legally mandated quotas, e.g quotas introduced in the constitution or by law, ussually the electoral law of the country, versus (2) voluntary party quotas, in which case quotas are written into the internal rules of a political party" (2007: 78)

Artinya, apabila kuota legal mengikat seluruh partai politik peserta pemilu karena hal tersebut sudah diatur oleh undang-undang (dan disertai sanksi bagi yang melanggar), kuota partai hanya berlaku pada partai yang bersangkutan, karena pengaturan kuota didasarkan pada inisiatif masing-masing partai.

Berdasarkan tabel 2, maka baik kuota legal maupun kuota partai sama-sama memiliki variasi berupa reserved seat. International Idea dalam "Atlas of Electoral Gender Quotas" (2016:25)menyebutkan bahwa "while legislated and voluntary candidate quotas regulate the minimum number of women or candidates... reserved seats stipulate number of women or representatives of an under-represented sex to be elected to legislative bodies". Reserved seat tidaklah mengatur jumlah minimum perempuan untuk duduk di parlemen, namun reserved seat langsung menetapkan berapajumlah perempuan yang harus masuk di parlemen. Sistem reserved seat ini dapat berlaku baik berdasarkan kuota legal maupun kuota partai.

Tabel 2. Regional Variations in Preffered Quota Type

\begin{tabular}{|c|c|c|}
\hline & \multicolumn{2}{|c|}{ Level } \\
\hline Mandate & $\begin{array}{c}\text { Candidate } \\
\text { Quotas }\end{array}$ & $\begin{array}{c}\text { Reserved } \\
\text { seat quotas }\end{array}$ \\
\hline $\begin{array}{l}\text { Legal Quotas } \\
\text { Constitutional } \\
\text { or law }\end{array}$ & $\begin{array}{l}\text { Latin America, } \\
\text { The balkans }\end{array}$ & $\begin{array}{l}\text { Arab Region, } \\
\text { South Asia, } \\
\text { Africa }\end{array}$ \\
\hline $\begin{array}{l}\text { Vpluntary } \\
\text { party Quotas }\end{array}$ & $\begin{array}{l}\text { The West, } \\
\text { Nordic Regn, } \\
\text { Africa, The } \\
\text { Balkans }\end{array}$ & $\begin{array}{l}\text { Marocco } \\
\text { (charter signe } \\
\text { by parties }\end{array}$ \\
\hline
\end{tabular}

Sumber: Electoral Gender Quota: Between Equality of Opportunity and Equality of Result, 2007: 79

Dari dua jenis utama kuota beserta variasinya pada tabel 2 , berikut ini adalah tabel yang menunjukkan praktek kuota di berbagai negara, yang memudahkan perempuan mendapatkan kursi:

Tabel 3. Jenis Kuota Negara dengan Keterwakilan Perempuan Tinggi

\begin{tabular}{clcl}
\hline No & \multicolumn{1}{c}{ Negara } & \% Perempuan & Quota \\
\hline 1 & Iceland & 47,6 & Yes* \\
2 & Nicaragua & 45,7 & Yes*** \\
3 & Spain & 39,1 & Yes*** \\
4 & Belarus & 34,5 & None \\
5 & Uganda & 34,3 & Yes**\# \\
6 & Serbia & 34,0 & Yes* \\
7 & Macedonia & 31,7 & Yes**\# \\
8 & Philippines & 29,8 & Yes* \\
9 & Australia & 28,7 & Yes* \\
10 & South Sudan & 28,5 & Yes** \\
\hline
\end{tabular}

Keterangan:

* One or more political parties adopted a voluntary measure to increase the number of women candidates

** Legislated candidate quota

*** Legislated and voluntary quotas

\# Seats reserved for women

Berdasarkan tabel yang diolah dari data Union Interparlementaire dalam "Women in Parliement in 2016" di atas, dari 10 negara yang disebutkan, terdapat empat negara yang menggunakan kuota partai, dua negara menggunakan gabungan kuota legal dan kuota partai, dua negara dengan gabungan kuota legal dan 
reserved seat, dan masing-masing satu negara yang menggunakan kuota legal dan tidak menggunakan kuota sama sekali. Sementara di Indonesia, praktek kuota legal yang diterapkan tidak efektif mendongkrak kursi perempuan, bahkan ketika sistem kuota tersebut disokong pemberlakuan zipper system, kuantitas dan kualitas keterwakilan politisi perempuan tidak juga signifikan.

Data pada tabel 3 dengan jelas dan tegas menunjukkan pentingnya peran partai politik dalam menjamin keterwakilan perempuan. Bahwa Kuota legal sebenarnya dapat pula digabungkan dengan kuota partai, namun kuota partai sendiri sebenarnya adalah jenis kuota yang paling efektif meningkatkan angka keterwakilan perempuan. Artinya, apa yang paling dibutuhkan dari pemberlakuan sistem kuota sesungguhnya adalah inisiatif dan peran aktif dari partai politik. Karena partai politik adalah hulu berbagai kebijakan publik sekaligus hulu terseleksinya pejabat publik, maka sudah sepantasnya partai politik mengambil peran yang lebih signifikan terkait peningkatan partisipasi perempuan.

\section{Empat Unsur Sistem Pemilu}

Sistem pemilu sebagai mekanisme konversi suara rakyat (pemilih) menjadi kursi, membutuhkan empat unsur atau empat variabel teknis antara lain district magnitude, nomination, balloting dan electoral formulae, di mana gabungan empat unsur inilah yang membentuk sistem pemilu (lihat Surbakti 2008, Pramono 2011, Kurniawan 2014, Susetyo 2015). Termasuk dalam kaitannya dengan pencapaian tujuan tertentu dari sistem pemilu, maka operasionalisasi empat unsur ini merupakan praktek yang embedded di dalam sistem pemilu.

Misalnya, apabila sistem pemilu proporsional bertujuan mewakili sebanyak mungkin suara kelompok di masyarakat, sedangkan sistem distrik lebih bertujuan pada tercapainya akuntabilitas pemilu, maka cara pencapaian tujuan-tujuan ini dapat ditempuh dengan mengadopsi model, prosedur, mekanisme tertentu dari empat unsur pemilu tadi. Operasionalisasi dari empat unsur ini termasuk dalam rangka mencapai tujuan lain seperti tercapainya angka tertentu pada keterwakilan perempuan.

Pada poin empat unsur inilah letak urgensi artikel ini, terlebih sejauh ini penulis tidak menemukan studi terdahulu yang mencoba menganalisis empat unsur sistem pemilu terhadap keterwakilan perempuan di Indonesia, kecuali pada buku "Meningkatkan Keterwakilan Perempuan" yang diterbitkan oleh Kemitraan pada tahun 2011. Namun selain tidak banyak data, buku tersebut juga tidak terkait dengan aturan pemilu terbaru yaitu UU 7/2017.

Di Indonesia, sistem pemilu yang diterapkan adalah sistem pemilu proporsional, secara umum sistem ini adalah sistem yang dianggap paling capable dalam meningkatkan angka keterwakilan perempuan. Seperti tampak pada tabel 4 berikut ini:

Tabel 4. Sepuluh Negara dengan Keterwakilan Perempuan Tertinggi, Juni 2016

\begin{tabular}{|c|c|c|c|}
\hline $\begin{array}{l}\text { Rank and } \\
\text { Country }\end{array}$ & $\begin{array}{c}\text { Number } \\
\text { of Women } \\
\text { Elected/ } \\
\text { Total } \\
\text { Number } \\
\text { of Seats }\end{array}$ & $\begin{array}{c}\text { Proportion } \\
\text { of Women } \\
\text { Legislators } \\
(\%)\end{array}$ & $\begin{array}{l}\text { Type of } \\
\text { Elctoral } \\
\text { System }\end{array}$ \\
\hline 1. Rwanda & $51 / 80$ & 63,8 & PR \\
\hline 2. Bolivia & $69 / 130$ & 53,1 & Mixed \\
\hline 3. Cuba & $299 / 612$ & 48,9 & $\begin{array}{l}\text { Plurality/ } \\
\text { majority }\end{array}$ \\
\hline 4. Seychelles & $14 / 32$ & 43,8 & Mixed \\
\hline 5. Sweden & $152 / 349$ & 43,6 & PR \\
\hline 6. Senegal & $64 / 150$ & 42,7 & Mixed \\
\hline 7. Mexico & $211 / 498$ & 42,4 & Mixed \\
\hline $\begin{array}{l}\text { 8.South } \\
\text { Africa }\end{array}$ & $168 / 400$ & 42,1 & PR \\
\hline 9. Ecuador & $57 / 137$ & 41,6 & PR \\
\hline 10. Finland & $83 / 200$ & 41,5 & PR \\
\hline
\end{tabular}

Sumber: Electoral Systems and Women's Representation, 2016

Dari sepuluh negara dengan pencapaian angka keterwakilan perempuan tertinggi, lima diantaranya menggunakan sistem proporsional, empat menggunakan sistem mixed member dan hanya satu negara yang menggunakan sistem pemilu mayoritas. Setelah tiga dekade persoalan keterwakilan perempuan memperoleh tempat secara global, sistem mixed member memang terbukti mampu meningkatkan keterwakilan perempuan, namun kemampuan sistem mixed member dalam meningkatkan keterwakilan perempuan masih belum mengalahkan popularitas dari penggunaan sistem pemilu proporsional.

Di banyak negara, sistem pemilu proporsional terbukti lebih mampu meningkatkan 
kehadiran perempuan, namun catatannya sistem proporsional tertutup jauh lebih efektif dibandingkan proporsional dengan daftar setengah terbuka apalagi proporsional terbuka penuh. Terkait sistem proporsional tertutup ini, Mirjam Aliik menuliskan sebagai berikut :

"Others have argued that PR systems increase women's representation because they are less candidate centred, emphasising party representation and reducing personal vote incentives (Rule 1987; Kenworthy and Malami 1999; Thames and Williams 2010). Until recent decades, most PR systems made voters choose between parties rather than candidates. For this reason, the closed list $P R$ systems are called party centred - the focus of the electoral contest is the differences between parties and not candidates'personal traits." (Who Stands in the Way of Women? Open vs. Closed lists and candidate gender in Estonia, 2015: 430)

Artikel tersebut memperkuat pendapat tentang bagaimana sistem proporsional tertutup lebih menguntungkan bagi perempuan, yaitu karena sistem ini adalah party centered dan bukan candidate centered. Sebagai dampaknya, sistem yang party centered ini mereduksi pemberian insentif tertentu dari kandidat kepada pemilih dan atau konstituen.

Selain perdebatan sistem proporsional terbuka atau tertutup, efektivitas sistem pemilu proporsional terhadap peningkatan angka keterwakilan perempuan juga terkait erat dengan pengoperasian unsur-unsur sistem pemilu antara lain seperti district magnitude, nomination, balloting, serta electoral formulae. Empat unsur ini dapat memberi implikasi baik positif maupun negatif pada praktek sistem proporsional, berikut ini adalah penjabarannya sesuai dengan pasal-pasal di dalam UU 7/2017.

Pertama, besaran daerah pemilihan (dapil) atau district magnitude, hasil penelitian Johnson Myers menyebutkan :

"In a study on 23 parliamentary democracies using proportional representation, rule (1978) found that list PR systems, in particular those with large district magnitudes, were very important in women gaining greater representation. The nordic countries, which were the most successful at electing women, had a wide range of district magnitudes. Finland had an average of 13 candidates per district, Sweden an average of 12 , Denmark an average of 10, and Norway had district magnitude ranges from 2-16 seats." (2016:11)

Besaran dapil, atau jumlah kursi yang diperebutkan dalam satu dapil secara umum terdiri atas dua pilihan yaitu single member constituency atau multi member constituency. Untuk dapil multi member constituency sendiri, terdapat tiga pilihan besaran dapil diantaranya yakni small constituency yang terdiri dari 2-5 kursi, medium constituency yang terdiri dari 6-9 kursi, serta large constituency yang terdiri dari 10 kursi atau lebih. Apabila melihat contoh dari empat negara Skandinavia maka besaran dapil mereka termasuk ke dalam large constituency. Begitu pula studi dari Stephen A. Meserve, et.all yang menyebutkan

"Perhaps most notably, PR systems featuring high district magnitudes seem to support female representation more effectively than systems that use single, or low district magnitudes (see e.g. Rule 1981, Norris 1985, Norris 1987, Rule 1987, Welch \& Studlar 1990, Matland \& Studlar 1996, Matland 1998, Rosenbluth, Salmond \& Thies 2006, Salmond 2006)"

Indonesia sendiri termasuk ke dalam sistem proporsional dengan besaran dapil sedang, karena sejak pemilu 2009 ditetapkan jumlah kursi tiap dapil antara 3-10 kursi, pun demikian dengan hasil revisi UU Pemilu yang memenangkan opsi A, menetapkan besaran dapil tidak berubah dari 3-10 kursi (UU 7/2017, pasal 187 ayat 2 ).

Bandingkan dengan UU No. 12 tahun 2003, pasal 46 Ayat 2 yang mengatur besaran dapil untuk anggota DPR, DPRD Provinsi, dan DPRD Kabupaten/Kota, menyebutkan bahwa setiap dapil mendapatkan alokasi kursi antara 3-12 kursi. Hasilnya, Pemilu 2004 memiliki capaian keterwakilan perempuan tertinggi sepanjang masa yakni sebanyak 18 persen dari 560 kursi anggota DPR.

Secara empiris, pengalaman di Indonesia maupun di banyak negara yang keterwakilan perempuannya cukup tinggi, semakin besar dapil akan semakin memudahkan perempuan memasuki parlemen, karena harga satu kursinya semakin rendah. Namun pada umumnya, upaya memperbesar dapil akan mendapatkan 
tantangan dari ide penyederhanaan partai yang selama ini mendapat dukungan dari partai-partai besar. Karena kepentingan partai besar untuk memperluas dan memperkuat dominasi kekuasaan mereka ditempuh dengan memperkecil kemungkinan partai menengah dan kecil mendapatkan kursi. Dalam kaitannya dengan proses revisi UU Pemilu, perdebatan opsi A hingga opsi $\mathrm{F}$ terkait besaran dapil inipun tidak muncul, seluruh opsi yang muncul sepakat mengusulkan besaran dapil sebesar 3-10 kursi, artinya UU 7/2017 secara eksplisit menginginkan tatanan demokrasi dengan sedikit partai pemenang pemilu.

Unsur Kedua, terkait dengan pola pencalonan (nomination), yaitu siapakah yang mengajukan calon apakah partai politik, perseorangan, atau keduanya. Jawaban atas pertanyaan ini bergantung pada siapa yang menjadi peserta pemilu apakah perseorangan, partai politik, ataukah keduanya (Surbakti, 2008: 34).

Pada UU 7/2017 pasal 172, disebutkan bahwa peserta pemilu anggota DPR, DPRD Provinsi dan DPRD Kabupaten/Kota adalah partai politik. Oleh karena peserta pemilu legislatif adalah partai politik, maka calon anggota legisatif (caleg) diseleksi dan diajukan oleh partai politik peserta pemilu. Pasal ini diperkuat oleh pasal 234 yang menyebutkan bahwa bakal calon anggota DPR, DPRD Provinsi, dan DPRD Kabupaten/Kota disusun dan ditetapkan oleh partai politik peserta pemilu.

Baik pasal 172 maupun pasal 234 menunjukkan luasnya kewenangan partai politik dalam menyeleksi serta menetapkan caleg, termasuk didalamnya adalah kewenangan menentukan caleg perempuan. Terkait dengan caleg perempuan ini, pasal 245 menyebutkan bahwa daftar bakal calon haruslah memuat keterwakilan perempuan paling sedikit 30 persen, ini artinya sistem kuota adalah sistem yang memenuhi unsur nomination dan mendapat legalisasi di dalam UU Pemilu.

Meserve (2012:9) yang melakukan penelitian kuantitatif pada 3.085 kandidat dari 73 partai politik yang tersebar di 12 negara Eropa menyimpulkan bahwa :

"Country-level quotas may generate binding, exogenous, pressure on parties to improve female nomination rates. Yet quotas will only improve women's representation if parties add female candidates to viable positions on their lists."
Artinya, efektivitas sistem kuota pada unsur nomination juga bergantung pada daftar calon dimana calon perempuan ditempatkan. Sehingga analisis terhadap proses nominasi calon perempuan tidak dapat meninggalkan konteks sistem pemilu proporsional, yakni bagaimana daftar calon yang diajukan oleh partai politik apakah daftar tertutup (closed lists system) atau daftar terbuka (open lists system).

Apabila sebelum pemilu 2004 Indonesia menerapkan closed lists system di mana pemilih tidak memiliki kemampuan menentukan siapa wakil yang akan mereka pilih karena nomer urut dalam Daftar Calon Tetap (DCT) ditentukan oleh parpol peserta pemilu. Pada pemilu 2004, 2009, 2014, dan termasuk pemilu 2019 mendatang (pasal 168 UU 7/2017) tiap-tiap UU Pemilu yang berlaku menyebutkan bahwa sistem pemilu yang berlaku adalah sistem proporsional terbuka, meski pada pemilu 2004 terdapat perbedaan dibandingkan pemilu 2009, 2014, dan 2019 karena penentuan pemenang pada 2004 masih didasarkan pada nomer urut.

Perubahan dari sistem tertutup menjadi terbuka membawa konsekuensi pada tingkat keterpilihan perempuan. Menurut Johnson Myers, tidak ada garansi sistem proporsional terbuka dapat meningkatkan angka keterwakilan perempuan "it can also prove very difficult to convince to vote for women once they are on the list.. The list PR system used in South Africa serves as a good example of how a closed party-list can enhance representation of women" (2016: 13).

Maka pilihan rekayasa sistem pemilu untuk memperbanyak keterwakilan perempuan, selain dapat dilakukan dengan memberlakukan besaran dapil yang besar, sistem proporsional yang diberlakukan dapat berkisar antara sistem tertutup atau sistem terbuka dengan penentuan pemenang berdasarkan nomer urut, seperti yang dipraktekkan pada pemilu 2004.

Persoalan lain yang dapat memengaruhi peluang terpilihnya perempuan dari unsur nomination ini juga meliputi penetapan nomor urut calon.

Berdasarkan tabel 5, efektivitas zipper system pada Pemilu 2009 dan 2014 menjadi dipertanyakan mengingat pemenang pemilu yang masih didominasi calon dengan nomer urut kecil. Meski sistem penetapan pemenang pemilu didasarkan pada mekanisme suara terbanyak, faktor nomor urut ternyata tetap memiliki pengaruh. 
Tabel 5. Presentase Caleg Terpilih Berdasarkan Nomer Urut

\begin{tabular}{|c|c|c|c|c|}
\hline Periode & $\begin{array}{l}\text { Nomer } \\
\text { urut } 1\end{array}$ & $\begin{array}{l}\text { Nomer } \\
\text { urut } 2\end{array}$ & $\begin{array}{l}\text { Nomer } \\
\text { urut } 3\end{array}$ & catatan \\
\hline $\begin{array}{l}\text { DPR RI } \\
(2009)\end{array}$ & $64,9 \%$ & $19,3 \%$ & $6,3 \%$ & $\begin{array}{l}90 \% \\
\text { terpilih } \\
\text { dari } \\
\text { urutan } \\
1-3\end{array}$ \\
\hline $\begin{array}{l}\text { DPR RI } \\
(2014)\end{array}$ & $62,2 \%$ & $16,9 \%$ & $4,4 \%$ & $\begin{array}{l}83 \% \\
\text { terpilih } \\
\text { dari } \\
\text { urutan } \\
1-3\end{array}$ \\
\hline
\end{tabular}

Sumber: Data KPU yang diolah Puskapol UI

Data Pemilu 2009 dan 2014 menunjukkan pencalonan perempuan dalam daftar nomor urut lebih banyak berada di nomer urut 3 , sementara laki-laki banyak ditempatkan pada nomor urut 1 (Ardiansa, 2015). Maka pada unsur nomination ini,peluang peningkatanketerpilihan perempuan di bawah zipper system tidak mungkin tanpa inisiatif partai untuk memberikan nomer urut kecil kepada perempuan.

Unsur Ketiga adalah unsur model pemberian suara (balloting) terdapat tiga poin penting yang terintegrasi pada persoalan balloting ini diantaranya yaitu, (1) apakah suara diberikan kepada partai politik atau kepada kandidat atau keduanya, (2) apakah pemberian suara dilakukan secara kategorik atau secara ordinal dengan cara merangking pilihan atas sejumlah calon, dan (3) apakah pemberian suara dilakukan dengan cara mencoblos atau terpelajar (dengan menuliskan nama atau nomor calon). Setiap pilihan dapat memiliki implikasi luas, terutama pada soal kepada siapakah calon terpilih akan bertanggung gugat (Surbakti, 2008: 35).

Terkait poin pertama, kedua, dan ketiga, pasal 353 UU 7/2017 mengatur metode pemberian suara pada pemilu dilakukan dengan cara mencoblos, baik mencoblos pada kolom partai maupun pada kolom kandidat. Artinya suara diberikan bisa kepada partai maupun kandidat, dan dilakukan secara kategorik dengan cara mencoblos.

Pasal 422 UU 7/2017 berikutnya mengatur bahwa penetapan calon terpilih untuk pemilu legislatif ditetapkan berdasarkan suara terbanyak yang diperoleh masing-masing calon. Persoalannya, apabila pemilih pemilu lebih banyak yang mencoblos kolom partai dibandingkan kolom kandidat, kemanakah suara partai tersebut dibagikan. UU 7/2017 tidak merinci persoalan ini, namun apabila kembali pada pemilu tahun 2009 dan 2014, suara partai akan diberikan berturut-turut kepada kandidat dengan suara terbanyak, hingga kandidat bersangkutan suaranya memenuhi harga satu kursi.

Implikasi dari pembagian sisa suara partai seperti ini, akan lebih menguntungkan kandidat yang mampu meraih suara banyak, sehingga proses ini terkait pula dengan berapa besar sumber daya yang dapat dialokasikan oleh kandidat, di mana perempuan cenderung tidak diuntungkan.

Eva Kusuma Sundari dari fraksi PDI Perjuangan, dalam salah satu wawancara mengungkapkan :

"pengalaman saya di tahun 2004 lebih mudah dibandingkan tahun 2009. (di tahun 2004) saya adalah anggota baru. Karena adanya peringkat dalam nomor, maka biaya politiknya sangat rendah.. Saya menghabiskan Rp. 225 juta, di mana Rp. 75 juta saya serahkan kepada partai dan sisanya saya pergunakan untuk kampanye saya.. Ketika suara terbanyak diputuskan (di tahun 2009), mati aku! Saya mengeluarkan lebih dari 1 miliar" (Perdana, 2014: 84-85).

Persoalan kemana suara diberikan (balloting) berimplikasi pada kemampuan perempuan mendapatkan kursi, bagi perempuan-perempuan di luardinasti politik perjuangan mendapatkan kursi cenderung tidak mudah. Seperti yang dituliskan O'Neil dan Domingo "lack of resources is the biggest barrier to retaining their parliamentary seats." (2016: 11).

Unsur Keempat, adalah formula pemilihan atau penetapan calon terpilih. Secara umum, metode penghitungan suara terbagi dalam dua kelompok besar, yakni metode kuota yang menghitung suara berdasarkan sisa terbesar atau the largest reminder, dan metode divisor yang menghitung suara berdasarkan rata-rata tertinggi atau the highest average (Kartawidjaja, 2003: 33). Sampai pada pemilu 2014, Indonesia mempraktekkan metode Bilangan Pembagi Pemilih (BPP) yang masuk dalam kelompok metode kuota.

Rapat paripurnaDPR-RIpada21 Juli2017, memutuskan bahwa konversi suara menjadi kursi yang sebelumnya mengggunakan metode 
kuota dengan varian hare, berubah menjadi metode divisor dengan varian sainte lague. Argumen yang dipakai untuk meninggalkan metode kuota hare lalu memilih metode sainte lague sebagai penggantinya, sangat bergantung pada tujuan yang hendak dicapai dari sistem pemilu, apakah bertujuan memperbanyak partai atau sebaliknya mengurangi jumlah partai.

Metode kuota dengan ciri pokok bilangan pembagi tidak tetap, karena bergantung pada jumlah penduduk/pemilih telah lama ditinggalkan karena terdapat paradoks sisa suara yang mampu mencuri kursi milik satu parpol atau daerah, dan kemudian memberikannya kepada parpol atau daerah lain yang umumnya merupakan parpol atau daerah besar.

Sedangkan pada metode divisor (sainte lague), bilangan pembaginya tetap karena tidak bergantung pada jumlah penduduk atau pemilih. Sehingga hasilnya, partai-partai kecil lebih berpeluang mendapatkan kursi dibandingkan pada metode kuota (Kartawidjaja, 2003: 31-62).

Apabila kembali pada soal upaya meningkatkan keterwakilan perempuan, efektivitas sistem proporsional tidaklah mudah tanpa kombinasi yang positif dari empat unsur sistem pemilu. Dari empat unsur yang telah disebutkan, unsur yang paling mungkin berimplikasi positif terhadap keterwakilan perempuan terletak pada unsur metode penghitungan suara. Dibandingkan pemilu sebelumnya, muncul kemungkinan untuk partai-partai kecil mendapatkan kursi, peningkatan ini umumnya juga linear pada probabilitas naiknya angka keterwakilan perempuan di parlemen.

Catatan Dirga Ardiansa (2015) yang membandingkan naik turunya perolehan suara partai pada pemilu 2009 dan 2014, menyebutkan bahwa penyederhanaan partai berkonsekuensi pada meratanya persaingan antar partai, sehingga distribusi perolehan suara antar partai tersebar dengan jarak perolehan suara yang relatif pendek, hal ini memberi dampak yang kecil terhadap keterpilihan perempuan.

Namun seberapa efektifkah kenaikan suara dibawah metode penghitungan divisor (sainte lague) ini pada pemilu 2019. Jawabannya, metode ini sebenarnya tidak benar-benar berdaya untuk meloloskan partai kecil, karena semangat dari metode ini bertentangan dengan pasal 414 UU 7/2017 yang berbunyi:

"Partai Politik Peserta Pemilu harus memenuhi ambang batas paling sedikit 4 persen dari jumlah suara sah secara nasional untuk diikutkan dalam penentuan perolehan kursi anggota DPR"

Maka dari seluruh unsur atau variabel di dalam UU 7/2017 lebih menunjukkan masih lemahnya aksesibilitas perempuan untuk masuk ke dalam parlemen. Tatanan sistem pemilu proporsional yang coba dibangun tidak cukup mampu mengubah kondisi under-represented dari kelompok perempuan. Tidak ada kebijakan afirmasi yang benar-benar mengafirmasi mereka, sehingga pada pemilu 2019 mendatang, caleg perempuan harus siap bertarung habishabisan seperti pada pertarungan Pemilu tahun 2009 dan 2014.

\section{SIMPULAN}

Secara empiris, sistem pemilu yang netral gender terbukti berakibat pada munculnya kesenjangan gender. Misalnya saat berkompetisi meraih dukungan, perempuan akan mengalami lebih banyak kendala ketika aturan pemilu disusun berdasarkan logika liberal. Resikonya, selain tidak terpenuhinya critical mass sebesar minimal 30 persen, sistem demikian juga dapat menghambat munculnya critical actors perempuan, karena yang mampu memenuhi prasyarat kompetisi akan terbatasi pada perempuan dari lingkaran oligarki kekuasaan.

Analisis terhadap UU 7/2017 menunjukkan bahwa sistem proporsional terbuka dan empat unsur sistem pemilu di dalam UU tersebut cenderung tidak signifikan terhadap upaya peningkatan keterwakilan perempuan. Meski hasil penelusuran literatur menunjukkan bahwa di banyak negara, peningkatan angka keterwakilan perempuan lebih efektif di bawah sistem proporsional dibandingkan pada sistem distrik atau mixed member. Namun di Indonesia, sistem proporsional daftar terbuka harus berhadapan dengan penentuan pemenang berdasarkan suara terbanyak.

Empat unsur yang membentuk sistem pemilu dalam UU 7/2017 juga tidak memungkinkan signifikansi keterwakilan perempuan. Keempat unsur sistem tersebut antara lain adalah (1) District Magnitude sebesar 3-10 skursi, yang tidak berubah dari Pemilu 2009 dan 2014 dan terbukti makin menurunkan kursi perempuan dibandingkan hasil pemilu 2004, (2) Nomination yang berbasis partai 
politik, menjadi tidak efektif karena harus berhadapan dengan proporsional daftar terbuka, sehingga meningkatkan insentif yang harus diberikan kepada pemilih, (3) Balloting yang diberikan kepada partai atau kandidat, namun melemahkan perempuan karena penghitungan akhir berdasarkan suara terbanyak, (4) Electoral formulae dengan metode divisor (sainte lague) yang semangatnya memudahkan partai kecil mendapatkan kursi, namun bertentangan dengan pengaturan ambang batas minimal 4 persen suara sah. Pada akhirnya, dalam rangka menjawab kontribusi UU 7/2017 tentang Pemilu terhadap keterwakilan perempuan, hasil pembahasan lebih menunjukkan bagaimana sistem ini tampaknya dibangun secara netral gender, sehingga cenderung tidak mampu meningkatkan akse-sibilitas perempuan terhadap kursi parlemen sampai dengan angka critical mass 30 persen pada pemilu 2019.

Padahal secara institusional, banyak pilihan perekayasaan sistem yang tersedia untuk meningkatkan keterwakilan perempuan. Misalnya dengan mempraktekkan sistem proporsional tertutup, mengembalikan besaran dapil seperti pemilu tahun 2004, atau dengan mempraktekkan kuota legal dan kuota partai sekaligus. Seluruh pilihan sistem ini patut dipertimbangkan guna mengakselerasi kesetaraan gender dalam demokrasi.

\section{DAFTAR PUSTAKA}

Aliik, M. (2015). Who Stands in the Way of Women? Open vs. Closed lists and Candidate Gender in Estonia. Journal East European Politics, Vol; 31, (4) 429451

Ardiansah, D.(2015).Menghadirkan Kepentingan Perempuan dalam Repre-sentasi Politik Indonesia. Jakarta: Puskapol UI

Azizah, N. (2013). Dilema Demokrasi Liberal: hambatan Normatif, Institusional, dan Praktikal dalam Pemberlakuan Kuota Perempuan di Indonesia. Jurnal HI UMY Vol 2, (4) 184-197.

Babbie, E. (2011). The Basics of Social Research. Belmont-USA: Wadsworth Cengage Learning.

Dahlerup, D. (2007). Electoral Gender Quota: Between Equality of Opportunity and Equality of Result. London: Routledge
Dahlerup, D. (2013). Atlas of Gender Quota. Sweden: International Idea

Grey, S. (2001). Women and parliamentary politics: Does Sixe matter? Critical Mass and Women MPs in the New Zealand House of the Representatives. Manchester, United Kingdom: Political Studies Association Conference.

Err, L. (2009). Impact of Electoral Systems on Women's Representation in politics. Council of Europe: Parliamentary Assembly.

Handayani, T. dan Sugiarti. (2008). Konsep dan Teknik Penelitian Gender. Malang: UMM Press

Hilman, B. (2017). Increasing Women 's parliamentary Representation in Asia and the pasific: The Indonesia Experience. Australia: The Australian National University.

Interparliementarie, Union. (2017). Women in Parliement in 2016 - The year in Review. Geneva: Courand

Kartawidjaja, Rochijat, P. (2003). Alokasi Kursi - Kadar Keterwakilan Penduduk dan Pemilih. Jakarta: Elsam

Kurniawan, N. (2014). Keterwakilan Perempuan di Dewan Perwakilan Rakyat Pasca Putusan Mahkamah Konstitusi Nomor 22-24/PUU-VI/2008. Jurnal Konstitusi Vol. 11(4) 693-713.

Lore, G.(2016). Women's Political Representation and Electoral Systems. Canada: Equal Voice.

Lovenduski, J. (2008). Politik Berparas Perempuan. Yogyakarta: Penerbit Kanisius.

Meserve. S. (2012). Gender, Incumbency, and Party List Nomination. Texas Tech University.

Myers, J \& Tracy-Ann. (2016). The Impact of Electoral Systems on Women's Political Representation. SpringerBriefs in Political Science.

NDI. (2016). Why Women in Politics. Washington: NDI

Norris, P. \& Inglehart, R. (2001). Women and Democracy: Cultural Obstacle to Equal Representation. Journal of Democracy Volume 12 (4) 126-140 
O’Neil \& Domingo, P. (2016). Women and Power - Overcoming Barriers to Leadership and Influence. London: Overseas Devlopment Institute.

Perdana, A. (2014). Wajah Aktivis Perempuan dalam Parlemen. Jurnal Perempuan 81, Vol. 19 (2) 73-93

Pramono, S. (ed). (2011). Meningkatkan Keterwakilan Perempan-Penguatan Kebijakan Afirmasi. Jakarta: Kemitraan

Puskapol UI. (2014). Profil Anggota Legislatif 2014-2019: Potensi Dominasi Fraksi Makin Kuat. Jakarta: Puskapol UI

Rahayu, R.I.(ed).(2014). The Success and the Barriers to Women's Representation in Southeast Asia. Jakarta: Kemitraan.

Soeseno, N. (2014). Perempuan Politisi dalam Partai Politik. Jurnal Perempuan 81 Vol. 19, (2) 95-124

Suara PKBI. (2018). $R \quad K U H P$ Rasa Kolonialisme: Tolak!. Diakses 10 Februari 2018, dari https://pkbi.or.id/rkuhp-rasa-kolonialisme-tolak/.

Surbakti, R. (2008). Perekayasaan Sistem Pemilu untuk Pembangunan Tata Politik Demokratis. Jakarta: Kemitraan.
Susetyo, W. (2015). Pengkajian Hukum tentang Tinjauan terhadap Efisiensi Pelaksanaan Pemilu di Indonesia. Jakarta: Kemenkumham

UN Women and UNDP. (2015). Inclusive Electoral Process. New York: UN Women and UNDP

Virgint, E. (2016). Electoral Systems and Women's Representation. Ottawa, Canada: Library of Parliament.

Undang-undang No. 12 Tahun 2003 Tentang Pemilihan Umum. Jakarta: Sekretariat Negara

Undang-undang No. 10 tahun 2008 Tentang Pemilihan Umum Dewan Perwakilan Rakyat, Dewan Perwakilan Daerah, dan Dewan Perwakilan Rakyat Daerah. Jakarta: Sekretariat Negara

Undang-undang No. 8 tahun 2012 Tentang Pemilihan Umum Dewan Perwakilan Rakyat, Dewan Perwakilan Daerah, dan Dewan Perwakilan Rakyat Daerah. Jakarta: Sekretariat Negara

Undang-undang No 7 tahun 2017 tentang Pemilihan Umum. Jakarta: Sekretariat Negara 